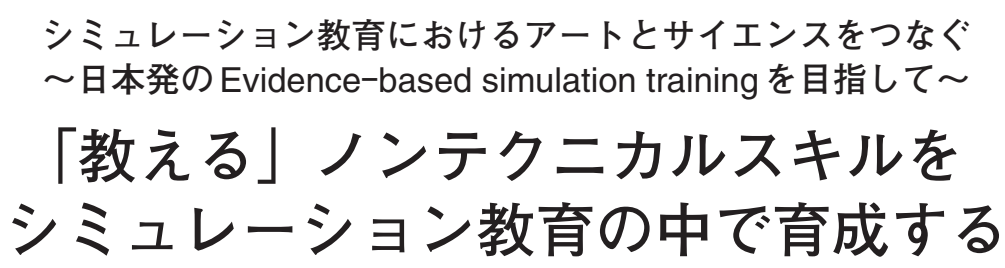

羽場政法 ${ }^{* 1}$ 駒澤伸泰 ${ }^{* 2}$ 植木隆介 ${ }^{* 3}$ 上農喜朗 ${ }^{* 4}$

[要旨］2006 年から米国心臓協会でBLS, ACLS教育に携わり，2008年から医学シミュレーシ ヨン学会で活動を開始した. 2011 年から鎮静トレーニングコースの運営にも関与するようになり, 2013 年から中心静脈・鎮静・気道管理困難を 1 泊2日で行う北大阪シミュレーションセミナー に継続的に参加している. それらのシミュレーション教育の中で,「受講生の理解を評価」「効果的 なコース運営」「各受講生の背景と目的に対応できるインストラクション」を考えるようになった. シミュレーション教育のコース設計は教育工学により設計されているが, 受講生に向き合うのはわ れわれインストラクターである. 学習者に対して, よき教育者であるためには, 1 回 1 回のコ一ス の解析とフィードバックを正確に行い，「教える」「伝える」というノンテクニカルスキルを養成す る必要がある. 教育者としてデブリーフィングを行い, 指導能力を涵養することが大切である. キーワード : シミュレーション教育法, デブリーフィング, ノンテクニカルスキル

\section{I＼cjkstart自身のシミュレーション教育歴を振り返る}

現在，さまざまな種類のシミュレーション教育が 公募にて開催されている。それらの母体は, AHA-Basic Life Support(BLS)やACLS, Pediatric Advanced Life Support(PALS) 等は日本ACLS協会および日本 循環器学会, Japan Advanced Trauma Evaluation and Care(JATEC) やImmediate Cardiac Life Support (ICLS) は日本救急医学会, そしてDifficult Airway Management(DAM) 実践セミナー, 鎮静トレ ーニングコースや超音波ガイド下中心静脈穿刺は日 本医学シミュレーション学会により運営されてい $ろ^{1) \sim 3)}$.

*1 ひだか病院麻酔科

${ }^{2}$ 大阪医科大学医学教育センター

*3 兵庫医科大学麻酔科学疼痛制御科学講座

*4 紀南病院麻酔科
筆者は, 2006 年から米国心臓協会 (AHA) でBLS, ACLS教育に携わり，2008年から医学シミュレーシ ヨン学会で活動を開始した。2011年から鎮静トレ ーニングコースの運営にも関与するようになり，さ まざまな教育開発に関わるようになった。これらの 活動の中で, AHAのコースは成人教育原理等に基 づいたコースデザインが行われていることに比し て，日本医学シミュレーション学会のコースは開発 から時間経過が少ないことから, 教育工学的検証が 薄いことに気付いた。しかし，AHAのコースでの 5 年間の指導経験が鎮静トレーニングコース開発に 大きく役立ったことは事実である。この点から，筆 者はシミュレーショントレーニングにおける指導能 
(a)

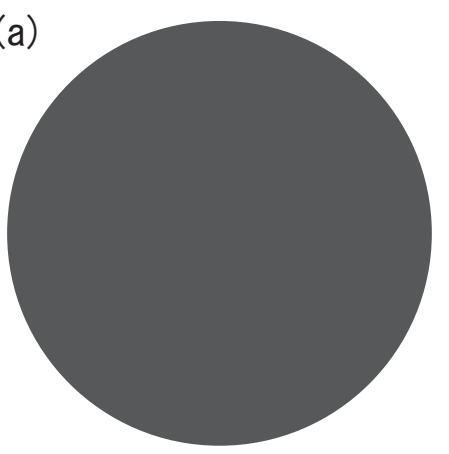

(b)

口強くそう思う

ロそう思う

ロどちらでもない

そう思わない

ロ全くそう思わない

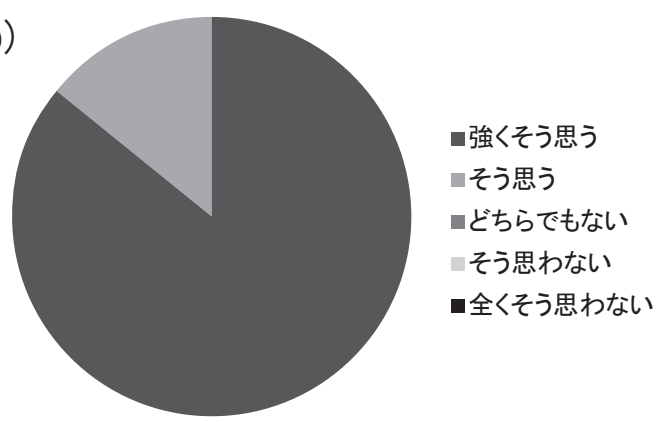

(c)

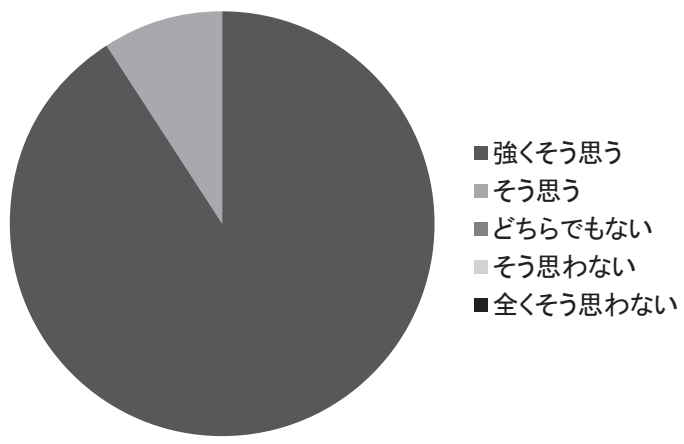

図1気道管理困難セミナー

(a)テクニカルスキル, (b) ノンテクニカルスキル, (c) 医療安全管理

(a)

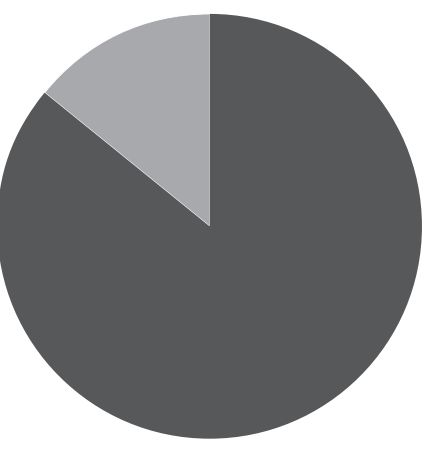

・強くそう思う

ロそう思う

ロどちらでもない

そそう思わない

ロ全くそう思わない

(b)

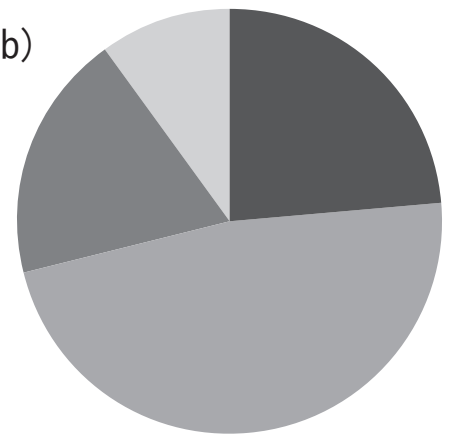

(c)

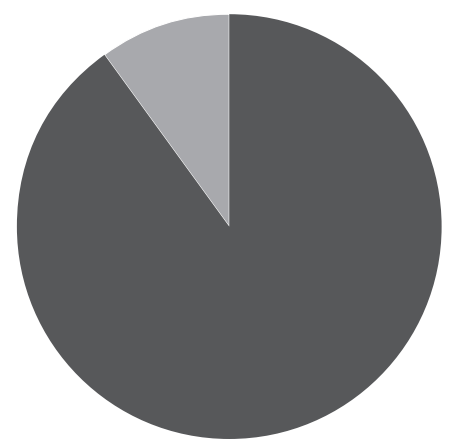

・強くそう思う

モそう思う

・どちらでもない

そう思わない

—全くそう思わない
ロ強くそう思う

ロ そう思う

ロどちらでもない

そう思わない

曰全くそう思わない

図2 中心静脈穿刺セミナー
(a)テクニカルスキル， (b) ノンテクニカルスキル, (c) 医療安全管理 
(a)

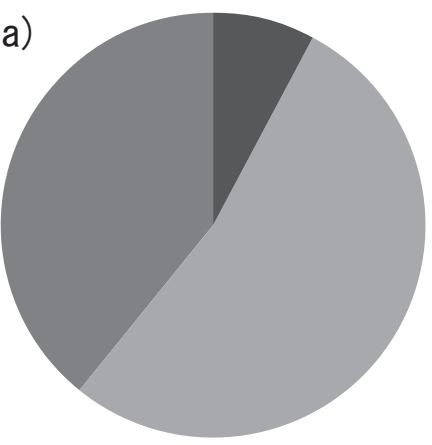

(b)

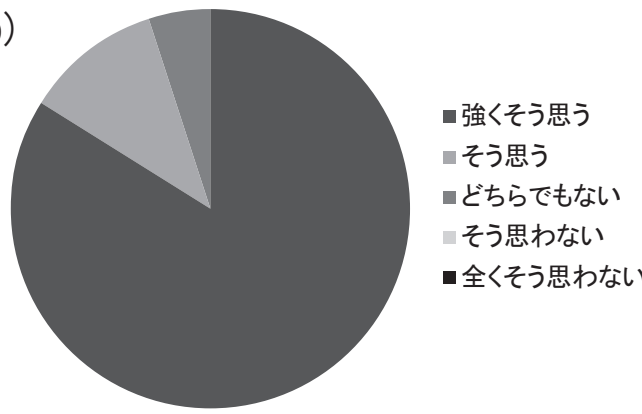

(c)

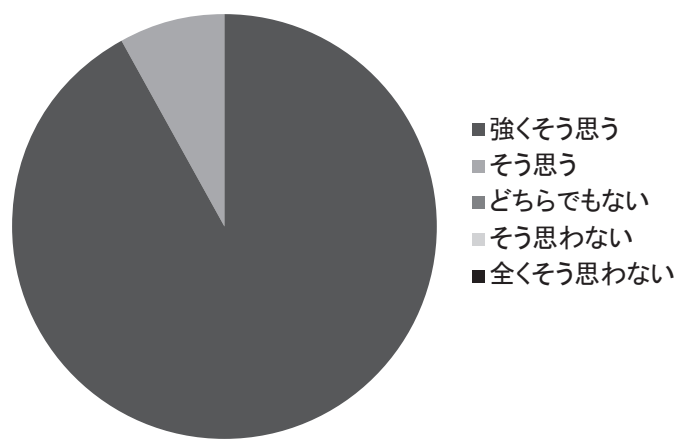

図3鎮静セミナー

(a)テクニカルスキル, (b) ノンテクニカルスキル, (c) 医療安全管理

力には「経験」が非常に重要であると感じている.

\section{II 北大阪シミュレーションセミナーの 運営に関わって}

2013 年から中心静脈・鎮静・気道管理困難を 1 泊 2 日で行う北大阪シミュレーションセミナーに継続 的に参加している。これまで単独でしか開催されて 来なかった医学シミュレーション学会のシミュレー ショントレーニングを他診療科医師にも効率よく受 講いただくための工夫である。鎮静コースは以前か ら多診療科・多職種が受講していたが，中心静脈や 気道管理困難では 8 割程度の受講生が麻酔・集中治 療以外の専攻医師であった。

インストラクターとして受講生が求めているもの を提供できているか不安であったため，受講生にお ける Learning Needs把握のための質問紙調査を行 った。2015年 12 月と 2016 年 7 月に大阪医科大学で 開催された DAM/CVC/SED実践セミナー受講生
（それぞれ 22，21，38名)に対し，受講前に Learning Needsについて質問紙調査を行った。内容は, (a)手 技的能力(テクニカルスキル)の習得に受講してい る, (b) 非技術的能力(ノンテクニカルスキル)の習 得に受講している, (c) 医療安全管理能力の習得に受 講している，の3項目に対し5段階評価(全くそう 思わないそう思わない どちらでもない そう思 う強くそう思う)とした。ささらに受講生は，学習 希望内容を自由回答形式で回答した。統計はカイ二 乗検定で行い $P<0.05$ を有意とした。それらの結果 を図1〜図3に示す。

気道管理困難セミナー：(a) は強くそう思うと全 員が回答した。（b）は，19名が強くそう思う，3名が そう思うと回答した。 (c) は，20名が強くそう思う， 2 名がそう思うと回答した。 $(\mathrm{a})$ ～(c) 間に有意差は なかった。

中心静脈穿刺セミナー：(a) は，強くそう思う 18 名，そう思う3名であり，(b) は，強くそう思う5名， 
表 1 気道管理困難セミナー, 中心静脈穿刺セミナー, 鎮静 セミナーにおける受講生からのフィードバック内容

\begin{tabular}{|c|c|}
\hline 気道管理困難 & $\begin{array}{l}\text { 挿管用声門上器具の使用方法 } \\
\text { 換気不能発生時の対応 } \\
\text { 気道管理困難対応カートの整備方法 } \\
\text { 自施設における多職種による訓練方法 }\end{array}$ \\
\hline 鎮静 & $\begin{array}{l}\text { 鎮静薬投与方法 } \\
\text { 鎮静深度評価方法 } \\
\text { 院内での鎮静医療安全体制の構築 } \\
\text { 個々の医療従事者に対する鎮静に対する } \\
\text { 危機意識の提唱方法 }\end{array}$ \\
\hline 中心静脈穿刺 & $\begin{array}{l}\text { 血胸, 気胸などの合併症発生時の対応 } \\
\text { 固定方法 } \\
\text { 感染予防法 }\end{array}$ \\
\hline
\end{tabular}

表2 シミュレーション教育法の流れ

\begin{tabular}{|c|c|}
\hline $\begin{array}{l}\text { STEP1: 事前準備 } \\
\text { ・ 学習目標の作成 } \\
\text { ・ 事前学習資料の配布 } \\
\text { ・ 教育方法の選定 } \\
\text { STEP2 : ブリーフィング(開始前説明) } \\
\text { ・ 心理的・物理的安全環境の確保 } \\
\text { ・ ルールの説明 } \\
\text { STEP3 : デブリーフィング(施行後) } \\
\text { ・ 深い振り返り } \\
\text { ・ フィードバック }\end{array}$ & $\begin{array}{l}\text { コース施行後の } \\
\text { インストラクターとしての } \\
\text { デブリーフィングと改善 }\end{array}$ \\
\hline
\end{tabular}

そう思う10名，どちらでもない 4 名，そう思わな い2名, (c) は, 強くそう思う19名, そう思う2名で あった. (a)〜 (c)の比較では, (a)と (b), (b)と (c)の 間に有意差が見られた (それぞれ $P<0.05)$.

鎮静セミナー：(a)は 3 名が強くそう思う，20名 がそう思う，15名がどちらでもない，と回答した。 (b) は，32名が強くそう思う，4名がそう思う，2名 がどちらでもないと回答した. (c)は，35名が強く そう思う，3名がそう思うと回答した。 (a)〜 (c)の 比較では (a)と (b)，(a)と（c）には有意差が見られた (それぞれ $P<0.05)$.

さらに, 学習希望内容としては, 表1のようなも のであった。これらの学習希望内容には, 学習目標
に含まれていないものもあり，大きな反省を得た。 これらの結果から，さまざまな受講生のニーズを痛 感し，指導に反映させた。

受講前にインストラクターがLearning Needsを 把握することは，受講生の満足度向上，コンピテン ス獲得に対し有効な可能性がある。

\section{III 指導するノンテクニカルスキルを シミュレーション教育の中で育成する}

これらのシミュレーション教育の中で,「受講生 の理解を評価」「効果的なコース運営」「各受講生の 背景と目的に対応できるインストラクション」の重 要性を考えるようになった").シミュレーション教 


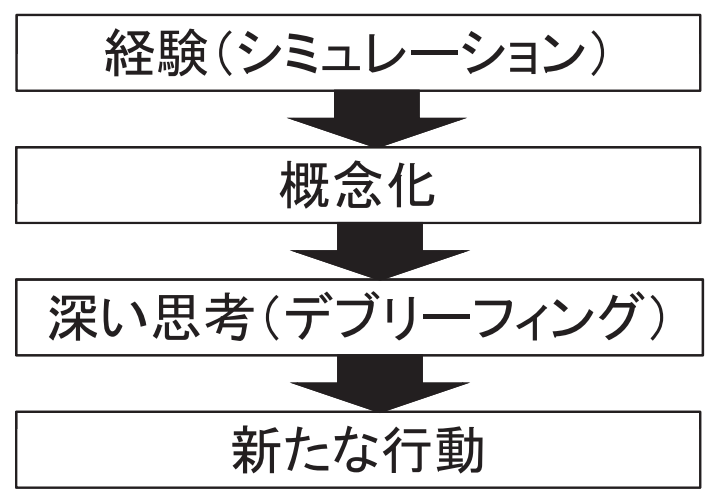

図4 シミュレーション教育法における経験型 学習論理

育のコース設計は表2のような教育工学により設計 されていることが多いが，受講生に向き合うのはわ れわれインストラクターである。学習者に対しよき 教育者であるためには，1回 1 回のコースの解析と フィードバックを正確に行い，「教える」「伝える」 というノンテクニカルスキルを養成する必要があ $ろ^{5), 6)}$.

シミュレーション教育を最大限に活用するために は，シミュレーションを行った際の指導者としての フィードバック・デブリーフィングが大切である. シミュレーション教育法は図4のような経験型学習 論理に基づいている。すなわち，シミュレーション による経験を，安全な環境で熟考することで臨床に おける新たなに行動につながる，というものであ る ${ }^{7)}$. しかし, これらの経験型学習論理は学習者だ けに限定されるものではなくインストラクターであ るわれわれにも当てはまる。1回1回のセミナーの 事前学習, 案内, 教育効果, 学習者からの意見を踏
まえ「教える」というノンテクニカルスキルを涵 養する必要がある。具体的な方策としては，このよ うなノンテクニカルスキルをインストラクターが効 率的に涵養するためにも，コース運営や工夫点, 改 善点等をメーリングリスト等で行うことが意義深い かもしれない，また，コース後に，相互のインスト ラクションに関して，デブリーフィング等を行うこ とも有効な可能性がある.

\section{参考文献}

1）駒澤伸泰，南敏明：2015年版米国心臟協会二次救命処 置ガイドラインの手術室蘇生への実践応用一周術期管 理チームによる危機対応能力育成のために一。 臨床麻 酔 $40: 147-151 ， 2016$

2）駒澤伸泰, 羽場政法, 植木隆介ほか：教育工学に基づ いた鎮静トレーニングコース (SED 実践セミナー)の改 良一模擬患者を用いた評価型シナリオの導入一，麻醉 $66: 996-1000,2017$

3）駒澤伸泰, 藤原俊介, 南敏明：麻酔・救急領域に扔け る医療安全向上のためのシミュレーション教育の意義 と課題. 日本臨床麻酔学会誌 $34: 214-221,2014$

4）阿部幸恵：医療に扔けるシミュレーション教育。日本 集中治療医学会雑誌 $23: 13-20,2016$

5) Sandahl C, Gustafsson H, Wallin CJ, et al. : Simulation team training for improved teamwork in an intensive care unit. Int J Health Care Qual Assur 26 : 174-188, 2013

6）羽場政法, 駒澤伸泰, 上嶋浩順ほか：ノンテクニカル スキル習得のためのシミュレーション教育の意義一 ANTS System の紹介一。 日本臨床麻醉学会誌 35 ：533537, 2015

7）駒澤伸泰，藤原俊介，趙崇至ほか：臨床教育と連続性 のあるシミュレーション教育の重要性一成人教育原理 の重要性一。本臨床麻酔学会誌 $36: 599-603,2016$ 


\title{
Significance of Instruction Skill Cultivation during Simulation-based Education
}

\author{
Masanori HABA ${ }^{* 1}$, Nobuyasu KOMASAWA ${ }^{* 2}$, Ryusuke UEKI*3, Yoshiroh KAMINOH*4 \\ ${ }^{* 1}$ Department of Anesthesiology, Hidaka General Hospital \\ ${ }^{* 2}$ Medical Education Center, Osaka Medical College \\ ${ }^{* 3}$ Department of Anesthesiology and Pain Medicine, Hyogo College of Medicine \\ ${ }^{* 4}$ Department of Anesthesiology, Kinan Hospital
}

I participated in basic life support and advanced cardiac life support courses of the American Heart Association in 2006 and have participated in various courses on difficult airway management and sedation of the Japanese Association for Medical Simulation since 2008. We have held two-day North Osaka Simulation Seminars which include central venous catheter, sedation, and difficult airway management since 2013. During instruction, I recognized the importance of evaluating participants' understanding, effective course management, and instruction which meets the background and objectives of participants. While the simulation-based training course is constructed by educational technology, instructors play an essential role. Simulation instructors should cultivate the most important skill -instruction- after the training course by debriefing on their performance during the course. Key Words : Simulation-based education, Debriefing, Non-technical skill

The Journal of Japan Society for Clinical Anesthesia Vol.40 No.1, 2020 